\title{
APORTES PARA O (DES)ENVOLVIMENTO DA AGRICULTURA CAMPONESA NO ENTORNO DA ROTA BIOCEÂNICA, EM MATO GROSSO DO SUL, BRASIL
}

\author{
CONTRIBUTIONS TO THE PEASANT AGRICULTURE \\ DEVELOPMENT AND INVOLVEMENT AROUND THE \\ BIOCEANIC ROUTE IN MATO GROSSO DO SUL, BRAZIL
}

\author{
Edgar Aparecido da Costa \\ Universidade Federal de Mato Grosso do Sul, Campus do Pantanal, Brasil \\ edgarac10@gmail.com
}

Glenda Helenice da Silva Rodrigues Bolsista de Extensão Universitária - Universidade Federal de Mato Grosso do Sul - Pantanal, Brasil glendah.rodrigues@outlook.com

Marcos Aurelio Saquet Universidade Estadual do Oeste do Paraná, Brasil saquetmarcos@ hotmail.com

\section{Resumo}

A agricultura camponesa se caracteriza pela produção de alimentos voltada para a existência familiar, para consumo próprio e para comercialização, bem como por um estilo de vida com íntima relação com a natureza e em comunidade. Carece de políticas públicas para a produção e venda dos seus produtos, que pode ser estimulada pela ampliação ou criação de novos circuitos de comercialização, especialmente curtos. Além disso, a "modernização" da infraestrutura viária pode ser um atrativo para a geração de novos negócios, impactando substantivamente o entorno de cada grande investimento. Por isso, o objetivo deste artigo é problematizar o debate do (des)envolvimento e apresentar algumas possibilidades de aproveitamento, pelos camponeses, das singularidades territoriais do entorno da passagem da rota bioceânica no estado de Mato Grosso do Sul. Utilizou-se, como metodologia de pesquisa, dados secundários do IBGE sobre a agricultura e a pecuária, entrevistas com técnicos de extensão rural e trabalho de campo no trecho de Campo Grande a Porto Murtinho, passando pelas cidades de Sidrolândia, Nioaque, Guia Lopes da Laguna e Jardim. Observou-se que a agricultura camponesa pode se beneficiar da proximidade espacial com a rota bioceânica, desde que os sujeitos tenham suporte político do Estado, de universidades, instituições de pesquisa e de organizações não-governamentais que valorizem a importância da sua cultura na produção de alimentos por meio dos circuitos curtos de comercialização.

Palavras-chave: Abordagem territorial. Camponeses. (Des)envolvimento territorial. Políticas públicas. 


\begin{abstract}
Peasant agriculture is characterized by the food production for the family living, through its own consumption and sale, as well as for a lifestyle with a close relationship with nature and in community. Public policies are needed for the production and sale of its products, which can be stimulated by the expansion or creation of new marketing circuits, especially short ones. Moreover, the road infrastructure "modernization" can be attractive for the generation of new businesses, substantially impacting the surroundings of each major investment. Therefore, the objective of this paper is to problematize the debate on the peasant agriculture development and involvement, presenting some exploitation possibilities of the territorial singularities surrounding the passage of the bioceanic route in the state of Mato Grosso do Sul by the peasants. Our research methodology were secondary data from IBGE on agriculture and livestock, interviews with rural extension technicians and fieldwork from Campo Grande to Porto Murtinho, passing through the cities of Sidrolândia, Nioaque, Guia Lopes da Laguna and Jardim. It was observed that peasant agriculture can benefit from the spatial proximity to the bioceanic route if the peasants have political support from the State, universities, research institutions and non-governmental organizations in valuing their culture in the food production and promote articulations through short commercial circuits.
\end{abstract}

Keywords: Territorial approach. Peasants. Territorial (de)involvement. Public policies.

\title{
Introdução
}

A ligação viária entre os oceanos Atlântico e Pacífico é um desejo antigo dos sujeitos do agronegócio brasileiro de chegar mais rapidamente e com menor custo dos fretes aos mercados asiáticos, bem como do capital industrial que certamente potencializará suas estratégias comerciais. Essas motivações incitam os governos nacionais e subnacionais a construir caminhos para a infraestrutura de escoamento da produção entre os países sul-americanos, como é o caso dos vários projetos da Integração da Infraestrutura Regional Sul-Americana (IIRSA).

Para o agronegócio brasileiro, a conexão com o Oceano Pacífico diminuirá oito mil quilômetros para alcançar o Oriente asiático. Através do Eixo Capricórnio da IIRSA, existem duas possibilidades de ligação passando pelo estado de Mato Grosso do Sul: o subeixo Centro-Oeste/Bolívia/Peru e o Centro-Oeste/Paraguai/Argentina/Chile, entrando/saindo pelas cidades de Corumbá e Porto Murtinho, respectivamente (LE BOURLEGAT, 1998). 
A escolha da passagem da rota pela cidade de Porto Murtinho, ao invés de Corumbá, tem explicação mais política do que de infraestrutura. Para tanto, está sendo necessária a pavimentação rodoviária de largo trecho no Paraguai e a construção de uma ponte internacional sobre o rio Paraguai, na altura da cidade de Porto Murtinho. A redução da distância com o Sudeste asiático, em especial da China, tornará as commodities brasileiras mais competitivas no comércio internacional. Estima-se uma maior circulação de mercadorias e pessoas, geração de novos empregos e de novas atividades no entorno da rodovia (CABRERA, 2020).

Trata-se de uma rota definida a favor do mercado de commodities na lógica do capital. A infraestrutura rodoviária, uma vez criada, não atende apenas a exportação do agronegócio. Gera uma série de possibilidades para circulação de pessoas e de outras mercadorias. Como o campesinato liga-se a mercados baseados em circuitos curtos de comercialização, a rota abre novos nichos de mercados. Os produtos podem ser valorizados na medida em que incorpore a cultura camponesa e/ou a produção orgânica e seu alcance acontece pela ativação de redes de solidariedade em circuitos curtos de comercialização.

Assim, os camponeses também podem aproveitar as possibilidades geradas pela rota, tema que será tratado neste texto. Para tanto, parte-se das seguintes questões orientadoras: o que a agricultura camponesa do entorno da rota bioceânica possui e pode incrementar na sua geração de renda? $\mathrm{O}$ que pode ser feito para tornar a produção comercializável, sem perder as características basilares dessa forma de agricultura?

O objetivo deste artigo é problematizar o debate do (des)envolvimento e apresentar algumas possibilidades de aproveitamento, pelos camponeses, das singularidades territoriais do entorno da rota bioceânica no estado de Mato Grosso do Sul. O texto está estruturado com os procedimentos da pesquisa e mais três seções. A primeira contém uma breve reflexão sobre o (des)envolvimento e está focada em evidenciar o debate sobre a agricultura camponesa, fundamental para exposição das propostas de ação da seção final. Na segunda, apresentam-se os elementos da área de estudo através de uma perspectiva territorial pluridimensional, que ilustra as (in)capacidades enraizadas e que permite sinalizar para algumas possibilidades de intervenção colaborativa a favor da resiliência da forma camponesa de saber e fazer. 


\section{Recorte analítico e procedimentos da pesquisa}

A opção pelo recorte analítico de 20 quilômetros do entorno da rota bioceânica levou em consideração as despesas para deslocamento das famílias camponesas até as margens da rodovia onde poderá ser construído um entreposto comercial. Considerouse, ainda, que essa distância é razoavelmente atraente para os consumidores se deslocarem para a busca dos produtos, já que as estradas não possuem pavimento asfáltico.

Essa faixa de $20 \mathrm{~km}$ caracteriza, portanto, um território apropriado e produzido historicamente a partir da colonização sulista (entre Campo Grande e Porto Murtinho), tendo como base grandes, médios e pequenos estabelecimentos fundiários utilizados para a agropecuária de comodities. Coexiste a agricultura camponesa praticada nos assentamentos rurais e nas aldeias indígenas, com as singularidades próprias das diferentes atividades praticadas e da cultura de cada agrupamento social no território.

O trecho estudado é uma parte do eixo de infraestrutura CentroOeste/Paraguai/Argentina/Chile. Abrange o espaço entre Campo Grande e Porto Murtinho, no estado de Mato Grosso do Sul, Brasil, com extensão rodoviária de 439 km. A escolha se deu em razão de ser o objeto de análise do projeto de extensão universitária denominado "Construção Multidisciplinar do Corredor Bioceânico" (financiado por Emenda Parlamentar). Parte de Campo Grande e segue por Sidrolândia, Nioaque, Guia Lopes da Laguna, Jardim e Porto Murtinho, no sentido Leste-Oeste.

Anastácio, Bela Vista, Bonito, Caracol, Dois Irmãos do Buriti, Maracaju e Terenos foram incluídos na análise por apresentar terras no recorte analítico, apesar de não terem suas sedes cortadas pela rota (Mapa 1). Campo Grande foi excluído pelo fato de não possuir nenhum assentamento rural no recorte analisado e pela opção de supressão de extremidade (dados muito díspares dos demais municípios). Além disso, pelo fato de ser a capital estadual, é mais bem servida de políticas públicas.

São municípios bastante diferentes do ponto de vista do tamanho populacional. Apenas Sidrolândia (59.245) e Maracaju (48.022) possuem mais de 40 mil habitantes. Jardim (26.238), Anastácio (25.237), Bela Vista (24.735), Terenos (22.269), Porto Murtinho (17.298), Nioaque (13.862) e Dois Irmãos do Buriti (11.467) ficam entre 10 e 
30 mil habitantes. Guia Lopes da Laguna (9.824) e Caracol (6.182) são os menos populosos e não atingem 10 mil habitantes (IBGE, 2020).

Mapa 1: Recorte analítico do corredor bioceânico

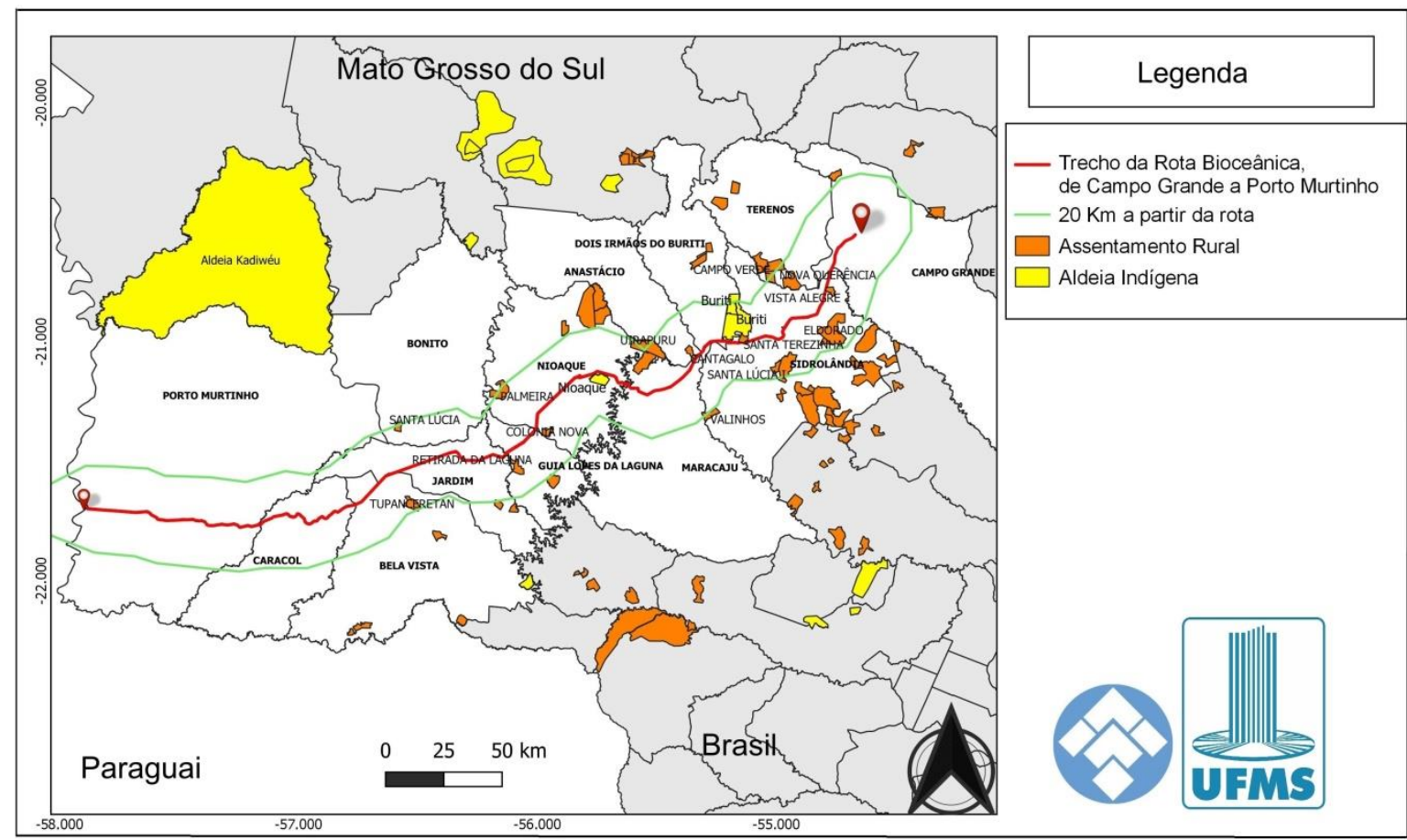

Fonte: IBGE

Org.: Os autores, 2021.

Para elaboração da Figura 1 foram utilizadas a base de dados do Instituto Nacional de Colonização e Reforma Agrária (INCRA) e da Fundação Nacional do Índio (FUNAI). A primeira permitiu inserir os assentamentos rurais e a segunda as terras indígenas. O recorte de 20 quilômetros e a rota bioceânica foram incorporados no QGIS, denominação comum e sigla de Quantum Geographic Information System. Trata-se de um software livre para trabalhar com Sistemas de Informação Geográfica (SIG), oferecido pela Open Source Geospatial Foundation (OSGeo). É bastante funcional, pois permite visualizar, editar, analisar dados geográficos e criar mapas com mais de uma camada de informação (BRUNO, 2017). A composição da Figura 1 é oriunda da sobreposição de cinco camadas (assentamentos, aldeias, recorte de $20 \mathrm{~km}$, corredor bioceânico e o estado de Mato Grosso do Sul) de informações geográficas.

A coleta dos dados secundários ocorreu no site do IBGE, utilizando os bancos de estatística do Sistema IBGE de Recuperação Automática (SIDRA), Pesquisa Agrícola 
Municipal (PAM) (IBGE, 2019a), Pesquisa da Pecuária Municipal (PPM) (IBGE, 2019b) e Censo Agropecuário de 2017 (disponíveis em: https://sidra.ibge.gov.br/) (IBGE, 2017).

Foram consideradas as principais produções agrícolas e da pecuária dos municípios cortados pelo corredor, quantidades produzidas, variedade, formas de apresentação dos produtos. Trabalhou-se numa perspectiva temporal dos oito anos mais recentes. Acredita-se que, desta forma, é possível perceber a existência (ou não) de regularidade produtiva relacionada a cada produto.

Como os dados da PAM e da PPM não revelam qual parte da produção é resultante dos camponeses, foram utilizadas duas outras estratégias metodológicas. Uma delas foi trabalhar os dados municipais da agricultura familiar disponível no Censo Agropecuário mais recente (IBGE, 2017). Isso permitiu visualizar o que está sendo produzido no entorno do corredor bioceânico e aproximar o olhar, mais de perto, para a produção camponesa - ainda que os dados não sejam diretamente correspondentes a ela. A outra foi o levantamento de dados primários com foco na produção dos camponeses.

Os dados do IBGE são referentes ao município como um todo. Portanto, buscouse qualificar as informações a partir da coleta de dados via telefone (em virtude do protocolo de distanciamento social), entre os meses de abril e setembro de 2020, com técnicos da Agência de Desenvolvimento Agrário e Extensão Rural do Mato Grosso do Sul (AGRAER). Foi indagado o que cada assentamento rural, na faixa de $20 \mathrm{~km}$ do corredor, produz em escala comercial ou com excedentes comercializáveis. Para tanto, contou-se com o apoio da coordenadora técnica da AGRAER-Corumbá/MS que realizou a mediação entre os pesquisadores e os técnicos da extensão rural dos municípios estudados. As informações coletadas foram organizadas e analisadas de forma qualitativa.

A fim de verificar in loco os excedentes da produção camponesa foi realizado um trabalho de campo para levantamento das atividades de comercialização de produtos, às margens do corredor bioceânico, no mês de junho de 2021. Foram observadas e contadas todas as estruturas de vendas ao longo da rodovia, com ou sem a presença de agricultores e consumidores. Identificamos a existência de apenas duas bancas em funcionamento e, nelas, realizamos entrevistas com os camponeses, 
respeitando os protocolos sanitários em vigor. Os nomes dos entrevistados não foram revelados por uma questão ética e política.

\section{A agricultura camponesa numa proposta de (des)envolvimento territorial}

Entende-se que o (des)envolvimento, assim como qualquer processo socialnatural, é contraditório, conflituoso e complexo. Portanto, vale a pena trabalhar para tentar ressignificar esse conceito à luz de uma concepção territorial histórico-crítica e pluridimensional, seja para pesquisar, seja para cooperar com os sujeitos estudados. Desse modo, (des)envolver significa envolver novamente, num processo de reterritorialização centrado na participação popular, no diálogo e na construção do presente e do futuro, de forma interdisciplinar e interinstitucional, conservando a cultura - neste caso, camponesa - e a natureza.

Os camponeses e seus conhecimento populares contribuem para gerar muitas das respostas de que precisamos cotidianamente, favorecendo o entendimento do "povo com sua própria ciência", para defesa das suas necessidades e identidades (FALS BORDA, 1981; SAQUET, 2021), especialmente, produzindo grande parte dos alimentos que estão, todos os dias, na nossa mesa.

Nesse sentido, a cooperação universidade-sociedade local é essencial quando feita por meio das pesquisas, das (in)formações e das ações debatidas e concretizadas solidariamente, integrando conhecimentos e técnicas, sujeitos urbanos e rurais, ciência e saber popular, produtores e consumidores (SAQUET, 2021). Aí o (des)envolvimento acontece com nossa colaboração, numa relação horizontal, tanto na pesquisa como na extensão universitária, ancorado nas singularidades culturais e ecossistêmicas, ou seja, territoriais.

Cada território tem especificidades que precisam ser (des)envolvidas considerando-se a solidariedade, as redes curtas de comercialização, a agroecologia, o artesanato, as relações de confiança, a conservação da biodiversidade etc., tentando contribuir efetivamente para a construção de uma sociedade mais justa e ecológica. $\mathrm{O}$ território, então, é resultado e condição fundamental do (des)envolvimento que pode assumir o significado da agricultura camponesa. 
A partir desses argumentos é possível traçar expectativas para ampliar a renda camponesa, valorizando sua identidade territorial para agregar valor ao seu produto e aproveitar, contraditoriamente, um projeto capitalista que não foi originalmente pensado para beneficiar o campesinato. $\mathrm{O}$ ingresso numa escala mais longa de comercialização só é possível, na lógica camponesa, se for mediado por instituições parceiras (universidades, ONGs), pelo menos até sua emancipação, e articuladas em redes campesinas.

Com isso, reforçamos a importância dos circuitos curtos e sugerimos a possibilidade de ampliar a escala desses circuitos de comercialização por meio do uso de redes de solidariedade camponesa. A ativação de territorialidades em escalas maiores que a local é possível, como demonstrado por Eduardo (2016) ao tratar de territorialidades em rede nas escalas extra-locais, tendo como exemplo as articulações continentais da Rede Ecovida de Agroecologia (REDE ECOVIDA). A resposta está na solidariedade entre os lugares da agricultura camponesa.

A existência de uma "casa brasileira de produtos da agricultura camponesa" numa grande cidade do Sudeste asiático, gerenciada por camponeses locais, é plenamente possível. A contrapartida poderia estar numa "casa chinesa", por exemplo, em Campo Grande, gerenciada por camponeses brasileiros. Para isso, a agroecologia e a certificação orgânica participativa são caminhos possíveis e necessários.

A agroecologia é, ao mesmo tempo, ciência, movimento e prática (GLIESSMAN, 2013). A produção agrícola está centrada no equilíbrio entre cultivares, tipo de solo, nutrientes, incidência de luz solar e umidade. A conservação da natureza, os policultivos e a biodiversidade dos agroecossistemas são desejados e buscados. Como ideologia, a agroecologia valoriza as diversidades culturais, a ancestralidade e compartilha os conhecimentos tradicionais com os da ciência. Trabalha-se com estratégias para a produção de alimentos saudáveis preservando o ambiente (ALTIERI, 2008).

A agricultura camponesa precisa ser pensada como resultante de "relações de produção não capitalistas", mesmo que no interior do sistema capitalista de produção. A sobrevivência no campo, a resistência à expropriação da terra é o limite da produção camponesa (OLIVEIRA, 2007). A família camponesa produz aquilo que é necessário para sua alimentação, com excedentes e outros produtos destinados para 
comercialização, assim, consegue adquirir pelo menos parte do que não produz. Às vezes, em razão das condições culturais e do meio em que vive, escolhe algumas cultivares ou criação de animais para gerar produtos de venda com vistas a adquirir alimentos, roupas, eletrodomésticos, utensílios, enfim, artigos para melhoria das suas condições de vida.

Os camponeses são entendidos a partir de um conjunto de elementos entrelaçados, conforme proposto por Tavares dos Santos (1984) e caracterizam-se: pela "força de trabalho familiar", pelas práticas de "ajuda mútua" com outras famílias, "parceria" para o desenvolvimento de algumas atividades, realização sazonal de "trabalho acessório" para ajudar na renda familiar, contratação de "jornada de trabalho assalariada" quando os braços familiares são insuficientes para alguma atividade, "socialização" da cultura camponesa passada de geração para geração, "propriedade da terra" e dos "meios de produção" e jornada de trabalho que varia em relação às escolhas produtivas.

Contudo, a partir da Revolução Verde, cabe questionar o controle camponês das sementes utilizadas, dos insumos para enfrentamento do ataque das plantas invasoras e para a fertilização dos solos. O pacote tecnológico apresentou soluções que economizava tempo e prometia aumento de produtividade. Empiricamente se observa, no estado de Mato Grosso do Sul, camponeses dependentes de insumos agrícolas para a produção, associando-se à lógica do agronegócio. Por outro lado, notam-se resistências de alguns grupos, como os participantes de projetos agroecológicos e é nesta direção que se deve pensar e construir o (des)envolvimento para/pelos camponeses com emancipação e o máximo possível de autonomia decisória.

Por isso, cabe destacar que Shanin (2008) já advertia que o campesinato não pode ser entendido como um somatório de elementos, mas como um modo de vida. A terra é condição de sua existência e seus saberes e fazeres são produtos do arranjo territorial. Nessa direção, vem sendo atribuída, aos camponeses, larga importância na conservação da natureza, na segurança alimentar e no enfrentamento das mudanças climáticas, dentre outros processos.

A experiência de campo tem demonstrado que as famílias camponesas se animam com os tipos de produção que geram aumento de renda, mas esmorecem diante dos insucessos produtivos e/ou de comercialização. Não são agricultores que costumam 
arriscar com investimentos em tecnologias. Quando o fazem são bastante cautelosos ou seduzidos pelos agentes de Assistência Técnica e Extensão Rural (ATER), pesquisadores das universidades públicas e Organizações Não-Governamentais (ONG).

Assim, propõe-se, neste trabalho, que os camponeses sejam compreendidos a partir de uma abordagem territorial histórico-crítica, pluridimensional e relacional (SAQUET, 2014), consoante já mencionamos quando nos referimos ao (des)envolvimento territorial. É primordial que se identifique e compreenda as relações oriundas da combinação espaço-tempo-território e se leve em conta a pluralidade de elementos e processos que se desenrolam nas diferentes escalas. As articulações territoriais são expressões das relações de poder e da disponibilidade e uso de tecnologias em cada tempo.

Assim, acredita-se que as propostas para a agricultura camponesa não podem ser implantadas de "cima para baixo". É preciso que sejam construídas nas bases, numa perspectiva horizontal, sem perder de vista as verticalidades, as redes que atravessam os territórios. Entretanto, é possível induzir ações de (des)envolvimento a partir de diagnósticos participativos, quando se permite que as comunidades discutam e indiquem seus desejos e necessidades, mediados por animadores territoriais (COSTA, ZARATE e MACEDO, 2012).

Parte-se do princípio de que as territorialidades são produzidas no âmbito dos indivíduos, das coletividades e das instituições para alavancar estratégias de interesse delas, para a conquista de autonomia decisória. Para isso podem se valer das relações territoriais, das redes de cooperação que perpassam os territórios e dos fluxos que se estabelecem por e a partir dos lugares de vida cotidiana (SAQUET, 2014, 2021).

\section{Elementos para uma abordagem territorial pluridimensional da área de estudo}

Corredor ou rota bioceânica é a denominação que vem sendo dada para um trajeto rodoviário que liga os Oceanos Atlântico (no Brasil) e Pacífico (no Chile), criado e oficializado em 2000 na cúpula de presidentes sul-americanos (QUINTANAR e LÓPEZ, 2003). A proposta é a ligar quatro países (Brasil, Paraguai, Argentina e Chile) e favorecer o comércio entre eles e com os países asiáticos, especialmente China e Japão. 
O trecho estudado, conforme já fora destacado, abrange o espaço entre Campo Grande e Porto Murtinho, no estado de Mato Grosso do Sul (Mapa 2).

Mapa 2: Detalhamento do trecho do corredor bioceânico em Mato Grosso do Sul, Brasil.

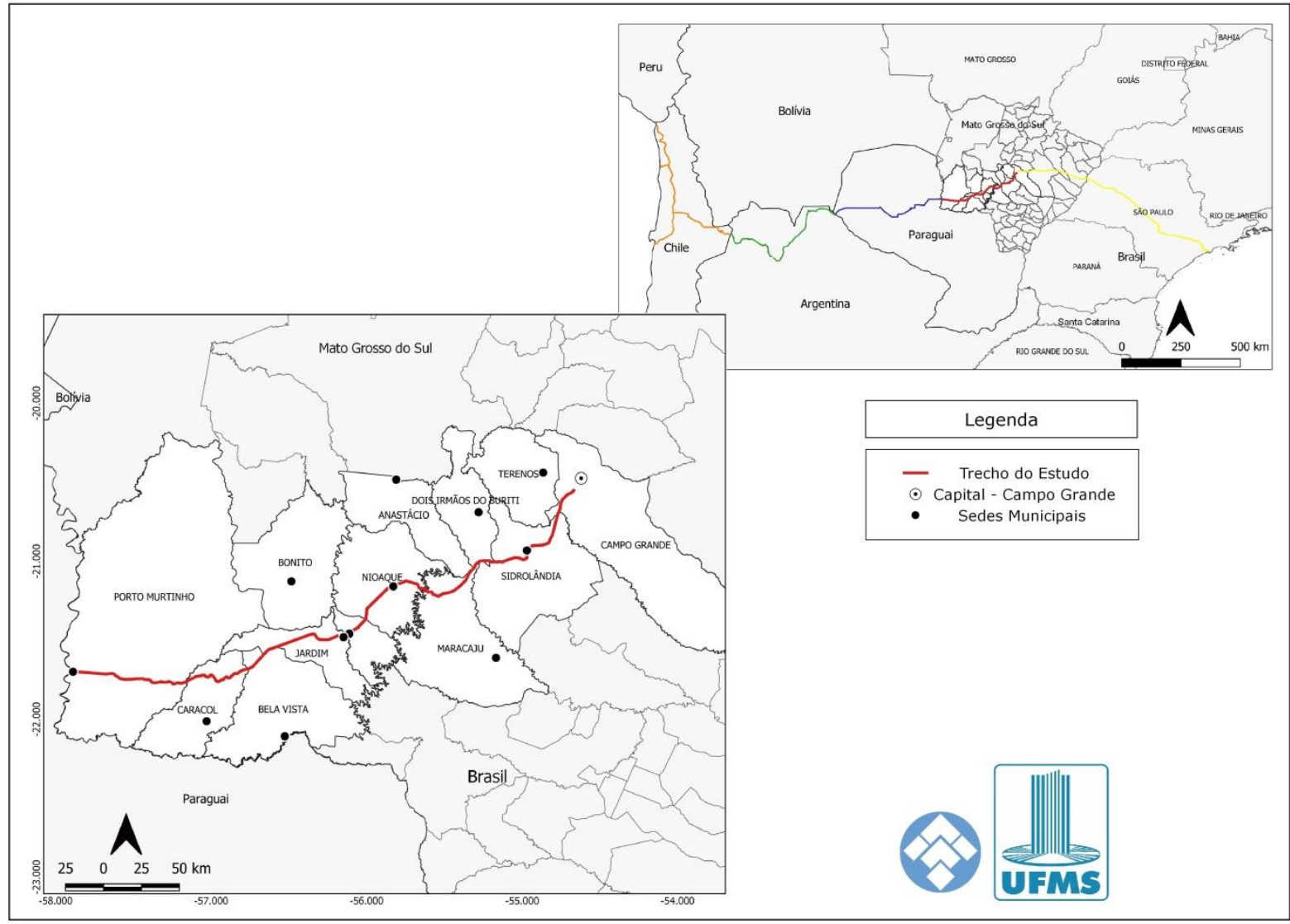

Fonte: IBGE

Org.: Os autores, 2021.

O estado de Mato Grosso do Sul possui uma posição geográfica estratégica na rota bioceânica, pois fica localizado entre os maiores centros comerciais do Brasil e dos países vizinhos. A implementação do corredor gera uma possibilidade de crescimento econômico, sobretudo para o agronegócio, pelo fato de ser um grande produtor e exportador de grãos, como a soja e o milho (CABRERA, 2020).

Contraditoriamente à lógica do capital, também, apresenta possibilidades para a agricultura camponesa ser dinamizada e estimulada para o (des)envolvimento territorial sustentável, desde que respeitadas suas lógicas produtivas e valorizados os saberes culturais e os ecossistemas do entorno. As famílias assentadas pela Reforma Agrária carecem de apoio técnico, recursos para viabilizar a produção, indicação de canais de 
comercialização, organização associativa e cooperativa. São em grande quantidade e, considerada no seu conjunto, podem atingir a escala comercial para o abastecimento alimentar da região. O trecho estudado (Figura 2) tem 2.320 famílias distribuídas em 17 assentamentos rurais.

Isso significa, sucintamente, que esse território é um potente espaço de organização política, luta e resistência camponesa que pode ser ampliada e qualificada por meio de projetos de cooperação e (des)envolvimento territorial próprio, ou seja, feito a partir das suas singularidades naturais (solos, climas, coberturas vegetais, águas) e sociais (econômicas, políticas, culturais), com o envolvimento respeitoso dos camponeses em questão. Assim, o território também significa um patrimônio da humanidade e, por isso, precisa ser cuidado tendo em vista sua sustentabilidade (SAQUET, 2021).

Prioriza-se, nesta análise, apenas os assentamentos da reforma agrária devido às matrizes ideológicas dos pesquisadores que acreditam ser um elemento da recriação da agricultura camponesa, fruto das lutas pela terra e para permanência nela. Também, porque esses camponeses são parte da população mais vulnerável do estado do Mato Grosso do Sul. Os assentamentos realizados através de financiamentos do Programa Banco da Terra, atual Terra Brasil - Programa Nacional de Crédito Fundiário - não foram analisados.

Considerando a faixa analítica de $20 \mathrm{~km}$ para ambos os lados da rodovia federal (BR 060, BR 419 e BR 267, em sequência Leste-Oeste) é possível observar uma expressiva quantidade de assentamentos rurais em Sidrolândia (5 com o total 1.075 famílias assentadas). O município possui a maior quantidade de assentamentos rurais na escala estadual (23). Maracaju e Nioaque dispõem de 3 e Terenos de 2 assentamentos. Bela Vista, Bonito e Guia Lopes da Laguna possuem um assentamento cada, enquanto Porto Murtinho, Anastácio e Caracol não têm assentamentos rurais (Quadro 1).

É importante lembrar que existem outras frações do campesinato que vivem a partir de relações de trabalho familiares no recorte estudado. Destacam-se os coletores de iscas, povos ribeirinhos denominados "Isqueiros". São famílias de pescadores espalhadas pelo Pantanal e, neste recorte, abrange grande parte do município de Porto Murtinho. Também, há presença da Terra Indígena de Nioaque (no município de mesmo nome) e da Terra Indígena Buriti (em Sidrolândia e Dois Irmãos do Buriti). 
Quadro 1: Assentamentos rurais, segundo a quantidade de famílias, área e data de criação nos municípios no raio de $20 \mathrm{~km}$ no entorno do trecho analisado do corredor bioceânico no estado de Mato Grosso do Sul

\begin{tabular}{|l|l|c|c|c|}
\hline Municípios & $\begin{array}{l}\text { Assentamentos } \\
\text { rurais }\end{array}$ & $\begin{array}{l}\text { Famílias } \\
\text { assentadas }\end{array}$ & Área (ha) & Data de criação \\
\hline Bela Vista & Tupanceretan & 80 & $2.546,44$ & $27 / 12 / 1996$ \\
\hline Bonito & Santa Lúcia & 31 & $1.026,74$ & $11 / 12 / 1998$ \\
\hline Guia Lopes da Laguna & Retirada da Laguna & 90 & $2.163,97$ & $13 / 02 / 1985$ \\
\hline \multirow{4}{*}{ Maracaju } & Santa Guilhermina & 224 & $7.994,72$ & $22 / 12 / 1997$ \\
\cline { 2 - 5 } & Cantagalo & 43 & $1.250,03$ & $22 / 09 / 2000$ \\
\cline { 2 - 5 } & Valinhos & 84 & $2.033,81$ & $21 / 12 / 2001$ \\
\hline \multirow{5}{*}{ Nioaque } & Colônia Nova & 74 & $1.314,15$ & $03 / 12 / 1987$ \\
\cline { 2 - 5 } & Palmeira & 113 & $4.172,71$ & $23 / 03 / 1998$ \\
\cline { 2 - 5 } & Uirapuru & 288 & $7.067,88$ & $23 / 12 / 1998$ \\
\hline \multirow{5}{*}{ Sidrolândia } & Vista Alegre & 48 & $1.030,82$ & $10 / 11 / 1999$ \\
\cline { 2 - 5 } & Geraldo Garcia & 182 & $5.775,21$ & $29 / 12 / 2000$ \\
\cline { 2 - 5 } & Santa Terezinha & 64 & $1.537,91$ & $13 / 08 / 2001$ \\
\cline { 2 - 5 } & Santa Lúcia I & 98 & $1.322,29$ & $09 / 03 / 2007$ \\
\cline { 2 - 5 } & Eldorado Parte & 69 & 834,07 & $05 / 12 / 2007$ \\
\cline { 2 - 5 } & Eldorado & 614 & $9.983,81$ & $15 / 07 / 2005$ \\
\hline \multirow{2}{*}{ Terenos } & Campo Verde & 60 & $1.918,55$ & $13 / 07 / 1987$ \\
\cline { 2 - 5 } & Nova Querência & 158 & $3.864,61$ & $26 / 11 / 1997$ \\
\hline
\end{tabular}

Fonte: INCRA, 2020.

Org.: Os autores, 2021.

A produção dos assentamentos rurais que estão localizados no recorte analítico é basicamente para existência familiar com vendas de excedentes (Quadro 2). Algumas atividades são praticadas com interesse comercial, como no caso da pecuária leiteira, hortaliças e legumes, mel, polpa de frutas, além do milho e da soja, quase sempre cultivados em parceria com sujeitos do agronegócio. Em pesquisa realizada na " $10^{\mathrm{a}}$ Feira de Sementes Nativas e Crioulas e de Produtos Agroecológicos em Juti/MS", foram entrevistados 30 agricultores de 15 municípios do estado de Mato Grosso do Sul e se observou que o leite $(56,67 \%)$ e a mandioca $(43,33 \%)$ são os principais responsáveis pela renda da agricultura familiar (NASCIMENTO et al., 2016).

O quadro 2 indica a diversidade da produção camponesa na área de estudo e seu potencial em escala comercial e de venda de excedentes. Vale ressaltar que a comercialização desses produtos já existe, mas carece de políticas públicas, apoio governamental e não-governamental para torná-los mais competitivas, a ponto de aumentar os ganhos do camponês. 
Aportes para o (des)envolvimento da agricultura camponesa no entorno da rota bioceânica, em Mato Grosso do Sul, Brasil
Edgar Aparecido da Costa

Glenda Helenice da Silva Rodrigues

Marcos Aurelio Saquet

Quadro 2: Assentamentos rurais, segundo municípios e escala de produção agropecuária no raio de $20 \mathrm{~km}$ no entorno do trecho analisado do corredor bioceânico

no estado de Mato Grosso do Sul

\begin{tabular}{|c|c|c|c|}
\hline Municípios & $\begin{array}{l}\text { Assentamentos } \\
\text { rurais }\end{array}$ & $\begin{array}{l}\text { Agropecuária (escala } \\
\text { comercial) }\end{array}$ & $\begin{array}{c}\text { Agropecuária (comercialização de } \\
\text { excedentes) }\end{array}$ \\
\hline Bela Vista & Tupanceretan & Bovinocultura de corte & $\begin{array}{l}\text { Hortaliças e pequenos animais } \\
\text { domésticos }\end{array}$ \\
\hline Bonito & Santa Lúcia & Bovinocultura de corte & $\begin{array}{l}\text { Hortaliças e pequenos animais } \\
\text { domésticos }\end{array}$ \\
\hline $\begin{array}{l}\text { Guia Lopes da } \\
\text { Laguna }\end{array}$ & $\begin{array}{l}\text { Retirada da } \\
\text { Laguna }\end{array}$ & $\begin{array}{l}\text { Doces (geleias } \mathrm{e} \\
\text { rapadura); pecuária de } \\
\text { corte; pecuária de leite } \\
\text { (laticínios) }\end{array}$ & $\begin{array}{l}\text { Hortaliças e polpa de frutas } \\
\text { (tamarindo, acerola, maracujá, } \\
\text { manga, guavira) }\end{array}$ \\
\hline \multirow{3}{*}{ Maracaju } & $\begin{array}{l}\text { Santa } \\
\text { Guilhermina }\end{array}$ & \multirow{3}{*}{$\begin{array}{l}\text { Acelga, berinjela, } \\
\text { beterraba, brócolis, } \\
\text { cebola, cenoura, colorau, } \\
\text { couve-flor, couve, fubá de } \\
\text { milho, milho verde in } \\
\text { natura, mel, pimentão, } \\
\text { polpa de fruta, quiabo, } \\
\text { rabanete, repolho, tempero } \\
\text { completo, tomate e vagem }\end{array}$} & \multirow{3}{*}{$\begin{array}{l}\text { Abóbora madura, abobrinha verde, } \\
\text { alface, banana, batata doce, cheiro- } \\
\text { verde, chuchu, doce de leite, erva- } \\
\text { cidreira, espinafre, farinha de } \\
\text { mandioca, feijão carioca, feijão } \\
\text { preto, goiaba, hortelã, laranja, } \\
\text { limão, mamão formoso, mandioca, } \\
\text { manjericão, maracujá, melancia, } \\
\text { pamonha, pão caseiro, pepino } \\
\text { comum e poncã }\end{array}$} \\
\hline & Cantagalo & & \\
\hline & Valinhos & & \\
\hline \multirow{3}{*}{ Nioaque } & Colônia Nova & $\begin{array}{l}\text { Pecuária } \text { de } \quad \text { corte } \\
\text { (principal) e } \\
\text { leite }\end{array}$ & $\begin{array}{l}\text { Suínos; aves; ovinos; apicultura; } \\
\text { mandioca; hortaliças; pomar } \\
\text { caseiro }\end{array}$ \\
\hline & Palmeira & $\begin{array}{l}\text { Pecuária de corte e } \\
\text { Pecuária de leite }\end{array}$ & $\begin{array}{l}\text { Suínos; aves; ovinos; apicultura; } \\
\text { melancia; mandioca; hortaliças; } \\
\text { pomar caseiro }\end{array}$ \\
\hline & Uirapuru & $\begin{array}{l}\text { Pecuária de corte; } \\
\text { pecuária de leite; soja } \\
\text { (sistema parceria); milho } \\
\text { (sistema parceria). }\end{array}$ & $\begin{array}{l}\text { Suínos; aves; ovinos; apicultura; } \\
\text { piscicultura (atividade em } \\
\text { expansão); mandioca; hortaliças; } \\
\text { pomar caseiro }\end{array}$ \\
\hline \multirow{6}{*}{ Sidrolândia } & Vista Alegre & Pecuária de leite & $\begin{array}{l}\text { Mandioca; abobrinha; batata doce; } \\
\text { queijo e hortaliças }\end{array}$ \\
\hline & $\begin{array}{l}\text { Geraldo } \\
\text { Garcia }\end{array}$ & Soja; milho & $\begin{array}{l}\text { pecuária de leite; hortaliças; } \\
\text { mandioca }\end{array}$ \\
\hline & $\begin{array}{l}\text { Santa } \\
\text { Terezinha }\end{array}$ & Pecuária de leite & Abacaxi; melancia; queijos \\
\hline & Santa Lúcia I & Pecuária de leite & Mandioca; hortaliças \\
\hline & Eldorado Parte & Pecuária de leite & Mandioca \\
\hline & Eldorado & Pecuária de leite & Mandioca; hortaliças \\
\hline \multirow[t]{2}{*}{ Terenos } & Campo Verde & $\begin{array}{lr}\text { Hortaliças; } & \text { quiabo; } \\
\text { berinjela; } & \text { pimentão; } \\
\text { abóbora; polpa de fruta }\end{array}$ & $\begin{array}{l}\text { Pecuária de corte; pecuária de leite } \\
\text { e derivados }\end{array}$ \\
\hline & $\begin{array}{l}\text { Nova } \\
\text { Querência }\end{array}$ & Pecuária de leite & Pecuária de corte e horticultura \\
\hline
\end{tabular}

Fonte: Informações orais dos agentes de ATER. Org.: pelos autores, 2021. 
Essa produção da agricultura camponesa se apresenta num contexto de algumas continuidades e descontinuidades produtivas municipais. A Pesquisa Agrícola Municipal (PAM) indica continuidade na produção de cana-de-açúcar, mandioca, milho e soja, com capacidade de gerar derivados para comercialização. O feijão apresenta descontinuidade produtiva somente em Guia Lopes da Laguna, a partir de 2015. Abacaxi, arroz, aveia, banana e melancia não mantém a regularidade de produção, tanto nos municípios quanto no período observado (2014-2019). Vale ressaltar que Sidrolândia possui a maior produção de abacaxi do estado. É possível observar, ainda, produções pouco significativas, como café, coco-da-baía, laranja, limão, maracujá, tangerina, tomate, trigo e uva com elevada variação anual (IBGE, 2019a).

A Pesquisa da Pecuária Municipal (PPM) mostra continuidade (de 2014 a 2019) na produção de leite, ovos de galinha, mel e lã nos municípios de Bela Vista, Bonito, Guia Lopes da Laguna, Maracaju, Nioaque, Sidrolândia e Terenos (maior produtor de ovos de galinha do estado). São produtos com potencial comercial (IBGE, 2019b).

O trabalho de campo realizado em junho de 2021 permitiu observar as localidades cuja produção de excedentes e de escala comercial são mais destacadas. O trecho rodoviário no entorno da cidade de Sidrolândia foi o único que tem negócios de beira de estrada ou marcas dele.

Entre Campo Grande e Sidrolândia foi encontrado um ponto fixo onde são vendidos produtos do Assentamento Santa Mônica (de Terenos), como doces, pimentas em conservas, abóboras, garapas, salames defumados, queijos, manteigas e produtos artesanais (cachaça, tábuas de churrasco, bacias de madeira, vinhos, chapéus etc.) (Fotografia 1). O proprietário possui autorização de funcionamento e está ali há cerca de 30 anos. É dono de lote naquele assentamento, vende produtos próprios e funciona como intermediário para os demais camponeses. Atua junto a outros membros da família e da igreja, revezando-se no atendimento aos clientes. Observou-se que todos os subprodutos possuíam selo de identificação e indicação de inspeção sanitária, aspecto importante que valoriza esses produtos no mercado. 
Fotografia 1: Sidrolândia/MS: Ponto de vendas de camponeses do assentamento Santa Mônica, de Terenos/MS, às margens da BR 060

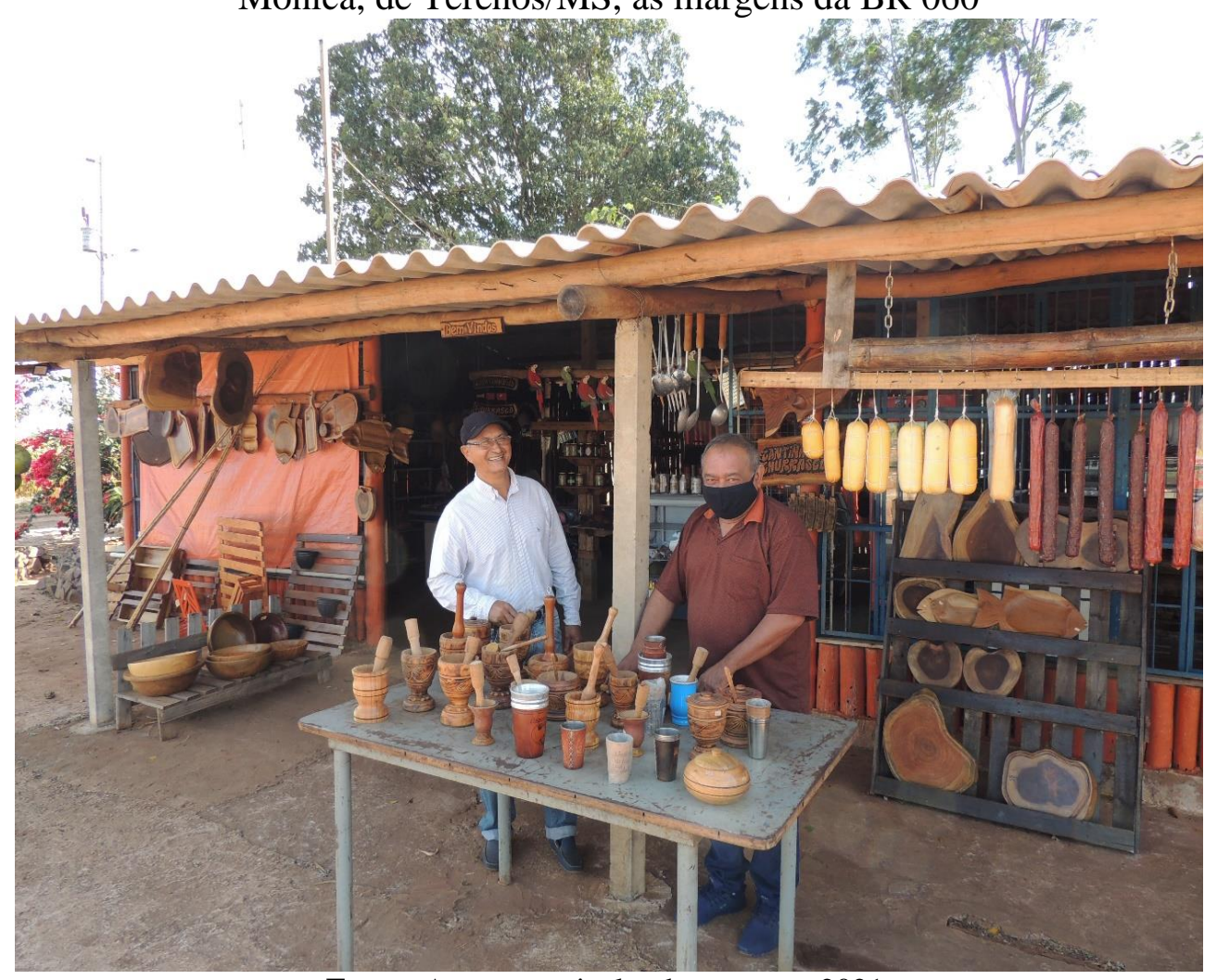

Fonte: Acervo particular dos autores, 2021.

Entre Sidrolândia e Nioaque, mais próximo da cidade de Sidrolândia, às margens da BR-060, foi encontrada outra banca da agricultura camponesa em funcionamento. Nela estavam sendo comercializados produtos do Assentamento Santa Terezinha (de Sidrolândia). O assentamento é referência nacional na produção de abacaxi e melancia, segundo relatos do entrevistado. O ponto é de um camponês, que vende seus produtos e de outros assentados. Foram encontrados no local bananas, lenhas, abacaxi, melancia, melão, doces e "biribá" (uma fruta exótica, típica da Amazônia, muito doce).

Em conversa com o camponês que produz "biribá" percebeu-se que ele deixa o produto pela manhã com o dono do ponto, informa o preço a ser vendido e no final da tarde passa para pegar o dinheiro das vendas e as sobras de produtos não comercializados. Isso significa mais aspectos que valorizam iniciativas como essa, como a reprodução de relações de confiança e solidariedade entre os camponeses, juntamente com a diversidade de produtos que a agricultura camponesa pratica em assentamentos rurais. 
Nesse mesmo trecho foram identificadas mais quatro estruturas de vendas que estavam fechadas (fotografia 2). Segundo informações dos camponeses entrevistados, aqueles pontos só funcionam no período da safra de abacaxi e da melancia. Assim, também se destaca, na rota pesquisada, a sazonalidade das vendas de produtos agrícolas escolhidos para finalidade comercial em determinadas épocas do ano.

Fotografia 2: Sidrolândia/MS: Ponto de vendas dos camponeses do assentamento Santa Terezinha às margens da BR 060

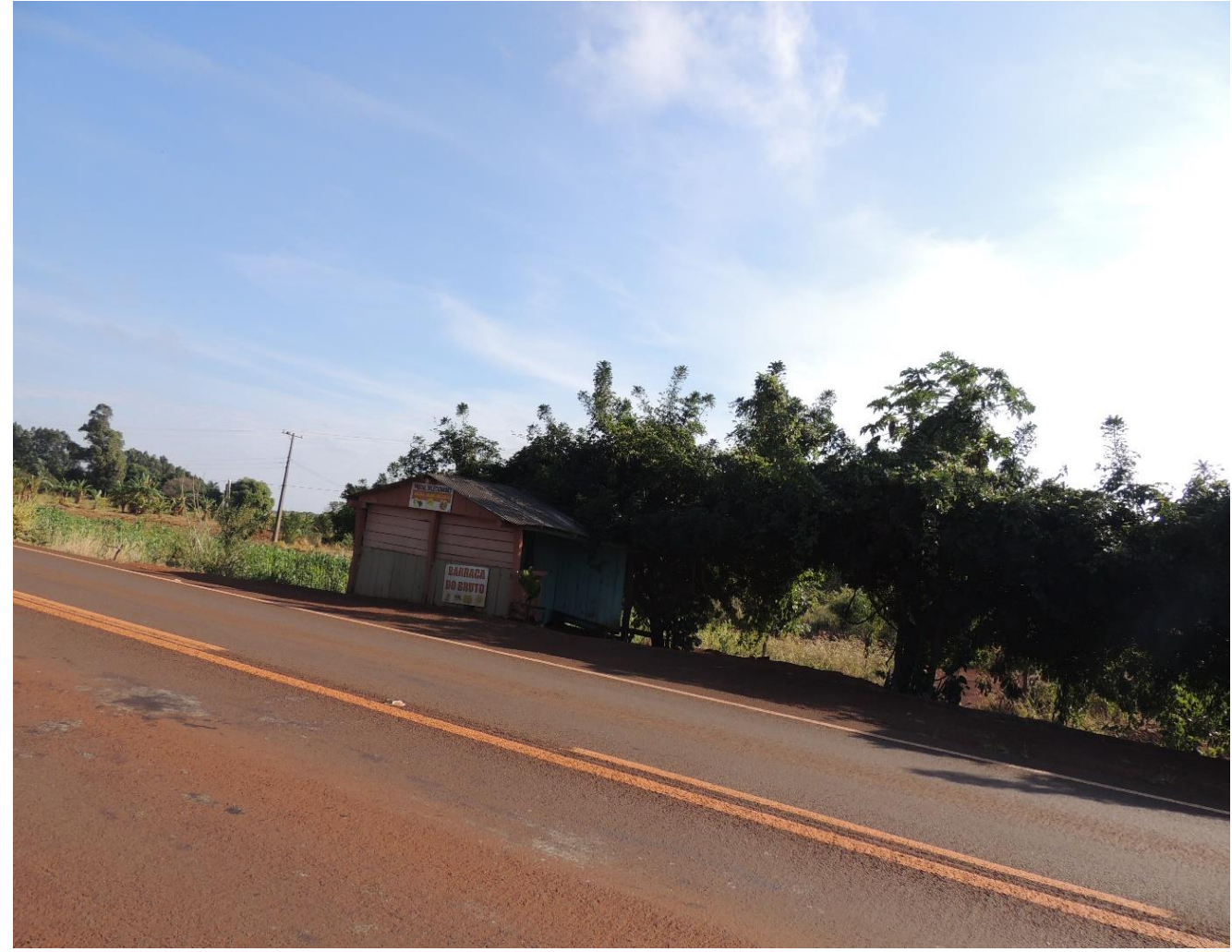

Fonte: Acervo particular dos autores, 2021.

Outro aspecto que precisa ser considerado, a partir das relações de solidariedade que ainda são reproduzidas, é o das capacidades de articulação entre as famílias camponesas. Individualmente há grandes possibilidades de se esbarrar na sazonalidade e nos infortúnios das intempéries naturais e do mercado. Por isso, a organização em associações de produtores rurais ou em cooperativas de produção e/ou de comercialização são valiosos instrumentos do desenvolvimento territorial sustentável.

As associações rurais são "sociedades formais com objetivo de integrar esforços e ações dos agricultores e seus familiares em benefício da melhoria do processo produtivo e da própria comunidade a qual pertencem" (MORAES; CURADO, 2004, p. 
24). São produtos de iniciativas grupais, normalmente de movimentos sociais, mas podem ser estimuladas por instituições governamentais, igrejas, ONGs e universidades. Não tem fins lucrativos e podem ser mediadoras entre os camponeses e as agências de extensão rural e prefeituras.

Assim como as associações, as cooperativas "servem como intermediário entre o mercado e as economias dos cooperados para promover o seu incremento, podendo promover a integração do produtor à cadeia produtiva" (BIALOSKORSKI NETO, 2000, p. 236). O uso da economia cooperativa pode gerar alternativas de desenvolvimento para as comunidades locais e, "se bem utilizada, ao longo do Corredor Bioceânico, possibilitará a visibilização da comunidade e do seu capital simbólico para os usuários da rodovia" (ASATO, 2019, p. 203).

Ao longo do corredor são observadas algumas cooperativas que operam com o objetivo de impulsionar a produção e/ou a comercialização da agropecuária. No que diz respeito à agricultura camponesa, percebe-se que as sedes das cooperativas estão localizadas nos municípios onde atuam (Anastásio, Dois Irmãos do Buriti, Porto Murtinho e Terenos), com destaque para a produção de leite.

Observa-se, no município de Terenos, a maior quantidade de cooperativas voltadas à agricultura familiar de produção e comercialização de produtos hortifrutícolas, de extrativismo do cerrado, pecuária leiteira e ovos. A Cooperativa Agrícola Mista de Várzea Alegre (CAMVA) é a maior produtora e comercializadora de ovos do Estado. Em vários de seus estabelecimentos cooperativados, verifica-se a utilização de mão-de-obra permanentemente contratada maior que a quantidade de membros familiares, além da característica de investimento para a produção de mercadorias. Essas funcionam como agricultura empresarial de pequena escala.

De qualquer forma, essas cooperativas revelam uma potência instalada na faixa territorial estudada, resultado do processo de colonização sulista feito na área a partir dos anos 1970-80, denotando características territoriais relacionadas à policultura, ao trabalho familiar, ao cooperativismo, à criação de pequenas cidades etc.

Os elementos e processos econômicos não são os únicos que impulsionam um grupo de famílias a buscar energias suficientes para avançar nos sistemas produtivos. Muitas vezes, o apoio é motivado pela utopia, por elementos psicológicos, religiosos, 
culturais e políticos, sobretudo dos movimentos sociais. Dentre essas possibilidades de impulso estão as igrejas e as Organizações Não Governamentais (ONGs).

As igrejas possuem papéis diversos e articulados com suas vocações. Existem grupos de trabalhos específicos com a questão da terra, como a Comissão Pastoral da Terra (CPT) que atua na luta e conquista da terra, defesa dos direitos humanos e no empoderamento das comunidades rurais. Outro exemplo é o Centro de Apoio e Promoção da Agroecologia (CAPA), ligado à Igreja Luterana, que atua na microrregião de Marechal Candido Rondon/PR, apoia atividades ligadas à agroecologia e combate ao uso indiscriminado de agrotóxicos (HORT; BERWALDT, 2018; EDUARDO, 2016).

Da mesma forma, as Escolas Famílias Agrícolas (EFAs), vinculadas a movimentos religiosos, desenvolvem importante trabalho com a pedagogia da alternância, capacitando os jovens para atuar no gerenciamento e cuidados com a propriedade rural, com envolvimento e protagonismo junto aos movimentos sociais, dentre outros. Na área de estudo, encontra-se a Escola Família Agrícola de Sidrolândia (EFASIDRO), no Assentamento Capão Bonito II, na estrada da Gameleira. Iniciou seu funcionamento em 2006 e atende jovens de 10 a 17 anos oriundos dos assentamentos do município e entorno (ASSUNÇÃO; BERNARDELLI, 2017).

As igrejas e as crenças, de um modo geral, representam importante papel na socialização e nas atitudes territoriais. Em outras palavras, as comunidades são orientadas a tomarem decisões baseadas em suas culturas e nos seus saberes, religiosas ou de ensinamentos passados de geração em geração, como as práticas de vida camponesa. Toda iniciativa, direcionada pelo Estado ou pela igreja, ou autoorganizativa (dos camponeses), política, cultural e ambiental, reflete no arranjo territorial que o indivíduo, a família ou o agrupamento social realiza na paisagem.

O arranjo territorial pode ser entendido como reflexo das técnicas e tecnologias utilizadas por determinada comunidade para sua vivência e o máximo de conforto possível. A técnica revela o momento e uma forma de se manifestar de um grupo e, ao mesmo tempo, sinaliza para a conquista do futuro. A técnica depende das tecnologias disponíveis em cada tempo, dos interesses e da capacidade econômica dos indivíduos (SANTOS, 2006). No que diz respeito à produção agrícola, as condições físicas do solo, vegetação, relevo e hidrografia devem ser favoráveis para o uso das técnicas, pois implica no emprego de mais ou menos recursos financeiros. 
A área de estudo apresenta duas seções distintas, seccionadas pela Serra de Maracaju. De Campo Grande até Maracaju é predominantemente encontrado solos do tipo latossolo vermelho, recomendados para uso agrícola com uso de adubações e calagem para o suprimento de base e correção da acidez. De Maracaju a Porto Murtinho, os solos variam de boa a baixa fertilidade natural com vulnerabilidade a erosões (BRASIL, 1982).

A vegetação predominante é a dos cerrados e, na porção mais ocidental, acontece em transição para o Pantanal. As máximas podem chegar a mais de $40^{\circ} \mathrm{C}$ a Oeste e as mínimas, na conformação da serra de Maracaju (Leste), podem atingir valores próximos ou abaixo de zero nos meses de maio a julho, com possibilidades de geadas. A precipitação média anual é de 1200 e $1800 \mathrm{~mm}$ e diminuem de Leste para Oeste (MATO GROSSO DO SUL, 2015).

Essas condições do meio natural associadas com a fraca organização social podem resultar em dificuldades para a produção e vida camponesa. Por outro lado, um grupo bem articulado pode buscar parcerias para alcançar seus objetivos coletivos e individuais. Podem tornar-se protagonistas do seu presente e do seu futuro. Existem inúmeras instituições públicas e privadas que podem apoiar ações de busca pela melhoria da vida camponesa, além das igrejas e ONGs, como o Estado (SAQUET, 2014).

O Estado tem um papel fundamental para impulsionar propostas de desenvolvimento territorial sustentável. Uma das iniciativas mais importantes são as políticas públicas focadas no atendimento das famílias camponesas. Exemplos disso são o Programa Nacional de Alimentação Escolar (PNAE) e o Programa de Aquisição de Alimentos (PAA). Além da federal, o Estado opera nas escalas das unidades federativas e dos municípios, que podem incentivar a produção agrícola, apoiar com assistência técnica e operar as políticas públicas a partir do local.

O poder político observado nos municípios estudados é marcado por descontinuidades administrativas (Quadro 3). De certa forma, nota-se predominância dos partidos PMDB (a partir de 2017 somente MDB - Movimento Democrático Brasileiro) e PSDB (Partido da Social Democracia Brasileira). Dos 48 mandatos contabilizados no período, 70,83\% foram desses partidos. Por outro lado, são escassos os casos de continuidades nos governos municipais (apenas oito reconduções) e, quando aconteceram, não foram superiores a oito anos no poder. 
Quadro 3: Partidos políticos vitoriosos nas eleições municipais no recorte analítico desta pesquisa, no estado de Mato Grosso do Sul, com destaque para as continuidades administrativas: 2008-2020.

\begin{tabular}{|l|c|c|c|c|}
\hline \multicolumn{1}{|c|}{ Município } & $2008-2012$ & $2012-2016$ & $2016-2020$ & $2020-2024$ \\
\hline Anastácio & PMDB & PSDB & PSDB & PSDB \\
\hline Bela Vista & PT & PMDB & PSDB & PSDB \\
\hline Bonito & PMDB & PT do B & PSDB & PSB \\
\hline Caracol & PR & PT & PR & PSDB \\
\hline Dois Irmãos do Buriti & PT & PMDB & PSDB & MDB \\
\hline Guia Lopes da Laguna & PMDB & PMDB & PSDB & PSDB \\
\hline Jardim & PSDB & PDT & PSDB & DEM \\
\hline Maracaju & PTB & PMDB & PMDB & PSDB \\
\hline Nioaque & PMDB & PSB & PSDB & PSDB \\
\hline Porto Murtinho & PSDB & PMDB & PSDB & PSDB \\
\hline Sidrolândia & PMDB & PSDB & PSL & PP \\
\hline Terenos & PMDB & PMDB & PMN & PSDB \\
\hline
\end{tabular}

Fonte: Tribunal Regional Eleitoral de Mato Grosso do Sul (TRE/MS).

Org.: Os autores, 2021.

As populações dos municípios estudados se caracterizam pela heterogeneidade de suas raízes territoriais. Os autóctones são indígenas, com maioria da etnia Terena, e populações tradicionais (ribeirinhos) do Pantanal, que vivem da coleta de iscas para pesca. Em comum, as famílias camponesas carregam os traços da elaboração de estratégias territoriais para estar e permanecer nos assentamentos rurais da Reforma Agrária. São (re)construídas identidades territoriais nos seus territórios de luta e de conquista e permanência na terra.

A diversidade de povos oriundos do Nordeste, Sudeste e Sul do Brasil, associados aos do próprio estado de Mato Grosso do Sul, compõem um arranjo cultural complexo. Por um lado, a diversidade cultural acena para inúmeras possibilidades de trato com a terra. Por outro, dificulta estratégias de ações coletivas, como aquelas ligadas ao associativismo e ao cooperativismo. Isso não significa na impossibilidade de arranjos locais a partir de esquemas, como a elaboração de "identidades de projetos" que, em conformidade com Castells (1999, p. 24), ocorre "quando os atores, utilizandose de qualquer tipo de material cultural ao seu alcance, constroem uma nova identidade capaz de redefinir sua posição na sociedade".

Assim, partir desses elementos e processos descritos, voltados para a valorização pluridimensional e para as possibilidades de articulação territorial para o 
desenvolvimento territorial sustentável, elencou-se algumas propostas para apoiar a agricultura camponesa do recorte territorial estudado, apresentadas, a seguir.

\section{Propostas de ação}

A efetivação de possibilidades para a agricultura camponesa envolve a disponibilidade de recursos e a capacidade para sua captação. Por isso foi elaborada esta seção com fins de demonstrar que existem vários canais de fomento e que podem ser acessados pelos camponeses, em função de seus interesses, de suas demandas espontâneas ou induzidas, de forma participativa por animadores e colaboradores territoriais.

A intenção é que as propostas apresentadas possam servir de ponto de partida para quaisquer organismos com interesse no (des)envolvimento territorial sustentável. Pode ser um camponês ou grupo desses, bem como universidades, igrejas, ONGs, governos municipais, agências de extensão rural. Os projetos devem estar atrelados aos interesses e desejos dos camponeses e assumidos por eles.

As propostas elaboradas e ora socializadas foram baseadas nas análises da produção já existente, mas que ainda carecem de estímulos para serem mais regulares. Dentre as possibilidades consideradas então as hortaliças e frutas produzidas em bases agroecológicas, aproveitamento de subprodutos da abóbora, cana, leite e mandioca associados ou não a sistemas agrícolas agroflorestais, mel e esforços para produção orgânica certificada.

A experiência com a extensão rural tem mostrado que várias famílias camponesas se apresentam desmotivadas para produzir na sua terra, dentre outros motivos, pela falta de assistência técnica ou por essa não considerar suas vocações produtivas. Por isso, a importância dos animadores e colaboradores territoriais que podem estimular e produzir identidades de projetos gerados pelo compartilhar dos desejos produtivos locais (COSTA, ZARATE e MACEDO, 2012).

Parte-se do pressuposto que a agricultura é uma atividade de risco e que quaisquer eventos da natureza (fortes chuvas, secas, tempestades, granizo etc.), grandes oscilações de preços, supersafras, pragas (gafanhotos, moscas), dentre outras situações, podem dizimar a produção. As famílias camponesas são, ainda, mais sensíveis a essas possibilidades pela diferença de recursos tecnológicos disponíveis, acesso à informação 
e locação de seguros agrícolas, quando comparadas ao agronegócio. O fracasso de lavouras comerciais financiadas pode significar a expropriação da família de suas terras. Neste sentido, existem duas possibilidades de financiamento para os projetos: as emendas parlamentares e os recursos a fundo perdido.

Para realização dos projetos propostos são indicadas as possíveis fontes de recursos (Quadro 4). Trata-se de uma relação não exaustiva, que considerou as organizações mais atuantes no Brasil e cuja atuação atrela-se às características da área de estudos, bem como às principais atividades com excedentes comercializáveis da agricultura camponesa.

Quadro 4: Propostas de projetos para alavancar a agricultura camponesa do entorno da rota bioceânica no estado de Mato Grosso do Sul

\begin{tabular}{|c|c|c|c|c|c|}
\hline Projetos & Objetivos & Responsáveis & Parcerias & Onde fazer & $\begin{array}{l}\text { Onde buscar } \\
\text { recursos }\end{array}$ \\
\hline $\begin{array}{l}\text { Produção } \quad \text { de } \\
\text { hortaliças }\end{array}$ & $\begin{array}{l}\text { Aumentar a } \\
\text { produção } \\
\text { construir } \\
\text { centrais de } \\
\text { processamento } \\
\text { de hortaliças }\end{array}$ & $\begin{array}{l}\text { Famílias } \\
\text { camponesas }\end{array}$ & $\begin{array}{l}\text { Agraer, } \\
\text { prefeituras, } \\
\text { Universidades, } \\
\text { ONGs. }\end{array}$ & $\begin{array}{l}\text { Nioaque, } \\
\text { Sidrolândia } \\
\text { e Terenos }\end{array}$ & $\begin{array}{l}\text { Emendas } \\
\text { parlamentares; } \\
\text { Care Brasil; } \\
\text { CERIS; IFAD; } \\
\text { MLAL }\end{array}$ \\
\hline $\begin{array}{l}\text { Processamento } \\
\text { de subprodutos } \\
\text { da abóbora }\end{array}$ & $\begin{array}{l}\text { Construir } \\
\text { centrais de } \\
\text { processamento } \\
\text { de abóboras }\end{array}$ & $\begin{array}{l}\text { Famílias } \\
\text { camponesas }\end{array}$ & $\begin{array}{l}\text { Agraer, } \\
\text { prefeituras, } \\
\text { Universidades, } \\
\text { ONGs. }\end{array}$ & $\begin{array}{l}\text { Nioaque, } \\
\text { Sidrolândia } \\
\text { e Terenos }\end{array}$ & $\begin{array}{l}\text { Emendas } \\
\text { parlamentares; } \\
\text { Care Brasil; } \\
\text { CERIS; IFAD; } \\
\text { MLAL }\end{array}$ \\
\hline $\begin{array}{l}\text { Miniusinas } \\
\text { processadoras } \\
\text { de farinha de } \\
\text { mandioca }\end{array}$ & $\begin{array}{l}\text { Construir } \\
\text { miniusinas para } \\
\text { processar } \\
\text { farinha } \\
\text { mandioca }\end{array}$ & $\begin{array}{l}\text { Famílias } \\
\text { camponesas }\end{array}$ & $\begin{array}{l}\text { Agraer, } \\
\text { prefeituras, } \\
\text { Universidades, } \\
\text { ONGs. }\end{array}$ & $\begin{array}{l}\text { Nioaque, } \\
\text { Sidrolândia } \\
\text { e Terenos }\end{array}$ & $\begin{array}{l}\text { Emendas } \\
\text { parlamentares; } \\
\text { Care Brasil; } \\
\text { CERIS; IFAD; } \\
\text { MLAL }\end{array}$ \\
\hline $\begin{array}{l}\text { Processamento } \\
\text { de subprodutos } \\
\text { do leite }\end{array}$ & $\begin{array}{l}\text { Construir } \\
\text { centrais de } \\
\text { processamento } \\
\text { de queijos e } \\
\text { doces }\end{array}$ & $\begin{array}{l}\text { Famílias } \\
\text { camponesas }\end{array}$ & $\begin{array}{l}\text { Agraer, } \\
\text { prefeituras, } \\
\text { Universidades, } \\
\text { ONGs. }\end{array}$ & $\begin{array}{l}\text { Nioaque, } \\
\text { Sidrolândia } \\
\text { e Terenos }\end{array}$ & $\begin{array}{l}\text { Emendas } \\
\text { parlamentares; } \\
\text { Care Brasil; } \\
\text { CERIS; IFAD; } \\
\text { MLAL }\end{array}$ \\
\hline \begin{tabular}{l}
\multicolumn{2}{l}{ Processamento } \\
de \\
da \\
dabprodutos \\
açúcar
\end{tabular} & $\begin{array}{l}\text { Construir } \\
\text { centrais de } \\
\text { processamento } \\
\text { doces e } \\
\text { rapaduras }\end{array}$ & $\begin{array}{l}\text { Famílias } \\
\text { camponesas }\end{array}$ & $\begin{array}{l}\text { Agraer, } \\
\text { prefeituras, } \\
\text { Universidades, } \\
\text { ONGs. }\end{array}$ & $\begin{array}{l}\text { Nioaque, } \\
\text { Sidrolândia } \\
\text { e Terenos }\end{array}$ & $\begin{array}{l}\text { Emendas } \\
\text { parlamentares; } \\
\text { Care Brasil; } \\
\text { CERIS; IFAD; } \\
\text { MLAL }\end{array}$ \\
\hline $\begin{array}{l}\text { Introdução de } \\
\text { sistemas } \\
\text { agrícolas } \\
\text { agroecológicos }\end{array}$ & $\begin{array}{l}\text { Garantir } \\
\text { produção com } \\
\text { segurança } \\
\text { alimentar para } \\
\text { consumo } \\
\text { familiar } \\
\text { comercialização }\end{array}$ & $\begin{array}{l}\text { Famílias } \\
\text { camponesas }\end{array}$ & $\begin{array}{l}\text { Agraer, } \\
\text { prefeituras, } \\
\text { Universidades, } \\
\text { ONGs. }\end{array}$ & $\begin{array}{l}\text { Guia Lopes } \\
\text { da Laguna, } \\
\text { Nioaque e } \\
\text { Sidrolândia }\end{array}$ & $\begin{array}{l}\text { Emendas } \\
\text { parlamentares; } \\
\text { ISFL; Care } \\
\text { Brasil; Cáritas } \\
\text { Brasileira; } \\
\text { CCFD; CERIS; } \\
\text { IFAD; Funbio; }\end{array}$ \\
\hline
\end{tabular}




\begin{tabular}{|c|c|c|c|c|c|}
\hline & & & & & $\begin{array}{l}\text { Boticário; } \\
\text { Oxfam } \\
\text { Intermón; } \\
\text { Manos Unidas }\end{array}$ \\
\hline $\begin{array}{ll}\text { Incentivo } & \text { à } \\
\text { produção } & \\
\text { orgânica } & \\
\text { certificada } & \end{array}$ & $\begin{array}{ll}\text { Apoiar } & \text { a } \\
\text { certificação } & \\
\text { orgânica } & \\
\text { participativa } & \\
\text { (via OPAC) } & \end{array}$ & $\begin{array}{l}\text { Agraer, } \\
\text { prefeituras } \\
\text { municipais e } \\
\text { famílias } \\
\text { camponesas }\end{array}$ & $\begin{array}{l}\text { Universidades, } \\
\text { APOMS, } \\
\text { ONGs. }\end{array}$ & $\begin{array}{l}\text { Nioaque, } \\
\text { Sidrolândia } \\
\text { e Terenos }\end{array}$ & $\begin{array}{l}\text { Emendas } \\
\text { parlamentares; } \\
\text { Cáritas } \\
\text { Brasileira; } \\
\text { CERIS; IFAD; } \\
\text { Manos Unidas }\end{array}$ \\
\hline $\begin{array}{l}\text { Produção de } \\
\text { frutas em bases } \\
\text { agroecológicas }\end{array}$ & \begin{tabular}{lr}
\multicolumn{2}{l}{ Apoiar } \\
comunidades \\
rurais mais \\
carentes & na \\
produção & de \\
frutas & em \\
sistemas & de \\
baixo custo & e \\
saudáveis &
\end{tabular} & $\begin{array}{l}\text { Famílias } \\
\text { camponesas }\end{array}$ & $\begin{array}{l}\text { Agraer, } \\
\text { prefeituras, } \\
\text { Universidades, } \\
\text { APOMS, } \\
\text { ONGs. }\end{array}$ & $\begin{array}{l}\text { Dois Irmãos } \\
\text { do Buriti, } \\
\text { Nioaque; } \\
\text { Sidrolândia, } \\
\text { Terenos }\end{array}$ & $\begin{array}{l}\text { Emendas } \\
\text { parlamentares; } \\
\text { ISFL; Care } \\
\text { Brasil; Cáritas } \\
\text { Brasileira; } \\
\text { CCFD; CERIS; } \\
\text { IFAD; Oxfam } \\
\text { Intermón } \\
\text { Funbio; } \\
\text { Boticário; } \\
\text { Manos Unidas }\end{array}$ \\
\hline $\begin{array}{lr}\text { Apoio } & \text { a } \\
\text { formação de } \\
\text { cooperativas de } \\
\text { comercialização } \\
\text { de mel }\end{array}$ & $\begin{array}{l}\text { Mediar a } \\
\text { formalização de } \\
\text { cooperativas } \\
\text { para viabilizar a } \\
\text { comercialização } \\
\text { do mel } \\
\text { produzido }\end{array}$ & $\begin{array}{l}\text { Agraer, } \\
\text { prefeituras } \\
\text { municipais e } \\
\text { famílias } \\
\text { camponesas }\end{array}$ & $\begin{array}{l}\text { Universidades, } \\
\text { ONGs. }\end{array}$ & $\begin{array}{l}\text { Jardim } \\
\text { Terenos }\end{array}$ & $\begin{array}{l}\text { Emendas } \\
\text { parlamentares; } \\
\text { Care Brasil; }\end{array}$ \\
\hline $\begin{array}{l}\text { Central de } \\
\text { processamento } \\
\text { do mel para } \\
\text { comercialização }\end{array}$ & $\begin{array}{l}\text { Construir } \\
\text { centrais de } \\
\text { beneficiamento } \\
\text { e embalagens de } \\
\text { mel }\end{array}$ & $\begin{array}{l}\text { Famílias } \\
\text { camponesas }\end{array}$ & $\begin{array}{l}\text { Agraer, } \\
\text { prefeituras, } \\
\text { Universidades, } \\
\text { ONGs. }\end{array}$ & $\begin{array}{l}\text { Jardim, } \\
\text { Nioaque, } \\
\text { Sidrolândia } \\
\text { e Terenos }\end{array}$ & \begin{tabular}{l}
\multicolumn{2}{l}{ Emendas } \\
parlamentares; \\
Care Brasil; \\
CERIS; IFAD; \\
MLAL
\end{tabular} \\
\hline
\end{tabular}

Fonte: Elaboração própria, 2021. Obs. Os significados das siglas são apresentados no texto, a seguir.

As emendas parlamentares estão previstas na Constituição Federal como forma de participação no orçamento e atendimento de demandas específicas dos partidos ou dos representantes eleitos. É uma espécie de barganha política dos deputados federais e senadores para atender os interesses das populações dos seus Estados. Desde que negociadas, as emendas parlamentares individuais podem atender projetos de seus interesses. É importante que sejam mediadas e aplicadas por instituições e organizações territoriais para minimizar a prática eleitoreira do clientelismo. Cabe ressaltar que a emenda parlamentar não substitui o desmonte das políticas públicas da agricultura familiar.

É possível, ainda, mediante articulações de atores territoriais (presentes ou que atuam no local e com algum poder de decisão), induzir os representantes estaduais a 
buscarem emendas parlamentares de bancada, que são em maiores volumes. A questão mais importante a perceber é a possibilidade de indução da destinação dos recursos dessa fonte pelos grupos sociais organizados. Em outras palavras, é possível solicitar esse tipo de recurso aos representantes estaduais na Câmara e no Senado Federal. Não se atende indivíduos, mas coletividades (ONGs, associações, sindicatos, cooperativas, prefeituras municipais etc.). São recursos financeiros a fundo perdido.

Recursos a fundo perdido, tecnicamente chamado de subvenção, é o equivalente a doação de dinheiro sem a necessidade de devolução. Pode ser destinado a empresas, associações, cooperativas ou, até mesmo, indivíduos. É feita por instituições públicas, privadas e não-governamentais (ONGs). Variam quanto ao montante de recursos a serem doados, fiscalização da execução financeira e prestação de contas, temáticas atendidas, editais de concessão e público atendido. Para essa categoria da agricultura camponesa listou-se algumas instituições que financiam projetos a fundo perdido e que podem ser acessadas por associações ou cooperativas e, em alguns casos, por grupos informais.

O Fundo BioCarbon para Paisagens Florestais Sustentáveis (ISFL) se preocupa com o uso sustentável dos recursos naturais. Investe, principalmente, em atividades que envolvam questões de gênero e inclusão social, capacitação e fortalecimento do grupo. Para a agricultura camponesa podem concorrer projetos que se orientem para reflorestamento ou agrofloresta. Assim, a formação de sistemas agroflorestais produtivos consorciando diversas espécies frutíferas são de interesse do Fundo. O processo de seleção dos projetos é baseado nos indicativos do Protocolo de Quioto (https://www.biocarbonfund-isfl.org/; acessado em 20/04/2021).

A Care Brasil se interessa pelo desenvolvimento local e financia ações de inclusão social de forma sustentável do ponto de vista social, ambiental, econômico e cultural. Prioriza o atendimento de projetos que envolvam o protagonismo das mulheres e dos jovens. A agricultora camponesa pode apresentar projetos que envolvam o incremento da produção agrícola e a geração de pequenos negócios (https://www.care.org/our-work/where-we-work/brazil/; acessado em 20/04/2021).

A Cáritas Brasileira apoia propostas ligadas à economia popular solidária (EPS) e de convivência harmoniosa com os biomas. Pode financiar projetos de até 20 mil reais para promoção da segurança alimentar e nutricional (SAN) e presta assessoria com 
vistas a criação de hábitos alimentares saudáveis, cultivos agroecológicos e de plantas medicinais (http://caritas.org.br/; acessado em 20/04/2021).

O Comité Catholique contre la Faim et pour le Développement (CCFD) interessa-se pelo financiamento de projetos ligados ao desenvolvimento rural sustentável de até 20 mil dólares. Dessa forma, organizações de bases comunitárias, universidades, associações e cooperativas podem apresentar suas propostas diretamente ao Comitê (https://ccfd-terresolidaire.org/; acessado em 20/04/2021).

O Centro de Estatística Religiosa e Investigações Sociais (CERIS) possui o Fundo de Apoio a Miniprojetos (FAM) que apoia projetos que envolvam compras comunitárias, beneficiamento agrícola e o desenvolvimento de atividades agrícolas. Apoia em torno de 200 projetos anualmente de pequenos montantes (http://www.ceris.org.br/; acessado em 20/04/2021).

O Fundo Internacional para o Desenvolvimento Agrícola (IFAD) é uma agência das Nações Unidas que buscar erradicar a pobreza e a fome no espaço rural de nações em desenvolvimento. O problema é que as propostas só podem ser apresentadas nas línguas inglesa ou espanhola. Isso exigirá maior capacidade de articulação dos camponeses que desejarem acessar esse fundo. São apoiados projetos para adoção de novas práticas agrícolas e de infraestrutura rural (https://www.ifad.org/es/home; acessado em 20/04/2021).

O Fundo Brasileiro para a Biodiversidade (Funbio) é destinado a apoiar iniciativas que visem à conservação/proteção da biodiversidade. Para a agricultura camponesa interessa as propostas de criação ou ampliação de sistemas agroflorestais (https://funbio.org.br/; acessado em 20/04/2021).

A Fundação Grupo Boticário de Proteção à Natureza vai na mesma direção do Funbio. Os projetos a serem apresentados precisam demonstrar sua articulação com os Objetivos de Desenvolvimento Sustentável (Agenda 2030), lançados em 2015 pela ONU (http://www.fundacaogrupoboticario.org.br/pt/Paginas/Inicial.aspx; acessado em 20/04/2021).

A Oxfam Intermón apoia projetos que visem combater a pobreza, as injustiças sociais e a fome no mundo. As iniciativas que visem ao desenvolvimento rural sustentável e SAN são muito bem-vindas. Cabe ressaltar que as propostas precisam ser 
escritas na língua espanhola (https://www.oxfamintermon.org/es) acessado em 20/04/2021.

A Manos Unidas possui um fundo que apoia comunidades carentes no mundo todo. Os projetos são na língua espanhola e, no caso da agricultura camponesa, inclui sistemas produtivos sustentáveis (https://www.manosunidas.org/; acessado em 20/04/2021).

Por fim, lista-se o Movimento Leigo da América Latina (MLAL) é uma organização não partidária, que reúne diferentes posições ideológicas. Apoia projetos de desenvolvimento econômico e ambientais de até 25 mil dólares (https://www.progettomondomlal.org/; acessado em 20/04/2021).

Existem inúmeras outras instituições em que se pode buscar recursos financeiros a fundo perdido. Essa listagem não teve a pretensão de esgotar as fontes possíveis, mas de apontar a existência delas. Algumas fontes governamentais são de ocorrência sazonal e podem ser acessadas, quando de sua ocorrência.

Enfim, cabe o protagonismo das famílias camponesas e o incentivo das prefeituras, movimentos sociais camponeses, universidades, igrejas, Ongs e agências de extensão rural para estimular e viabilizar projetos sustentáveis capazes de garantir a permanência e resistência desse grupo social no campo.

\section{Considerações finais}

A partir das reflexões deste trabalho é possível admitir que agricultura camponesa do entorno da rota bioceânica pode aproveitar-se das possibilidades comerciais geradas pela modernização da infraestrutura viária e acesso a novos mercados para incrementar sua geração de renda. Para tanto, são necessários enfrentamentos de alguns gargalos, próprios dessa forma de agricultura. Como se trata de uma produção com foco na sobrevivência da família, os excedentes comercializáveis, quando analisados individualmente, são pequenos. Quando se lança o olhar para a coletividade percebe-se que se trata de uma produção considerável e com capacidade comercial.

É importante a valorização dos saberes e fazeres camponeses, pois seu conteúdo agrega valor ao produto que, assim, com identidade própria, pode ter maior valor no mercado. O camponês não pode perder sua essência econômica (produção familiar para 
subsistência e venda de excedentes, ao seu tempo), pois sucumbirá pelas próprias leis de mercado. A estruturação de associações e de cooperativas, democraticamente instituídas e geridas por eles, pode garantir o acesso aos mercados e o modo de vida do grupo.

$\mathrm{O}$ estudo permitiu compreender algumas possibilidades e entraves para o impulso da produção da agricultura camponesa. Pensar o (des)envolvimento dessas famílias pressupõe o pleno envolvimento delas na discussão e identificação das suas vontades e necessidades, virtudes e potências, territorialidades e temporalidades que implicam suas trajetórias passadas, atuais e futuras.

Dentre as possibilidades de aproveitamento da rota bioceânica pela agricultura camponesa do entorno, no trecho analisado, estão os excedentes comercializáveis de alguns produtos. Mas, não somente desses. O despertar para novos sonhos, induzidos ou não por algum agente territorial, pode tornar uma atividade atraente e com potencial de ser alavancada. A indicação de fonte de apoio e de financiamento de emendas parlamentares e de instituições e ONGs a fundo perdido pode ser um importante mecanismo de estímulo. Além disso, as propostas aqui trazidas possuem caráter adaptativo e aplicativo em outros territórios apropriados pela agricultura camponesa.

Financiamento: Este trabalho foi financiado pela Universidade Federal de Mato Grosso do Sul, com recursos de Emenda Parlamentar (2020-2021).

\section{REFERÊNCIAS}

ALTIERI, Miguel. Agroecologia: a dinâmica produtiva da agricultura sustentável. 5.ed. Porto Alegre: Editora da UFRGS, 2008.

ASATO, Thiago Andrade; MARQUES, Heitor Romero; BUZARQUIS, Rodrigo Mussi; BORGES, Pedro Pereira. Perspectivas da economia criativa e do desenvolvimento local no Corredor Bioceânico. Interações, Campo Grande, v.20, p.194-210, jun.2019.

ASSUNÇÃO, Adenilso Santos; BERNARDELLI, Maria Lucia Falconi Hora. Educação popular e educação do/no campo: perspectivas para uma educação inclusiva - a Escola Família Agrícola em Sidrolândia - MS. Revista Brasileira de Educação do Campo, v.2, n.1, p.294-322, 22 abr.2017.

BIALOSKORSKI NETO, Sigismundo. Economia e gestão dos negócios agroalimentares: indústria de alimentos, indústria de insumos, produção agropecuária, distribuição. São Paulo: Pioneira, 2000. 
BRASIL. Ministério das Minas de Energia. Secretaria Geral. Projeto

RADAMBRASIL. Folhas SE.21 Corumbá, v. 27; Geologia; Geomorfologia;

Pedologia; Vegetação; Uso Potencial da Terra. Rio de Janeiro: IBGE, 1982.

BRUNO, Leandro Obadowiski. Aplicabilidade de Sistemas de Informações Geográficas (SIGs) livres nas ciências ambientais: o uso do QGIS. Rev. Bras. Gest. Amb. Sustent., v.4, n.8, p.321-326, 2017.

CABRERA, Fabiane Oliveira Moreti. Implementação da rota bioceânica no Estado de Mato Grosso do Sul: uma análise sobre a dinâmica econômica e suas implicações.

Revista Eletrônica da Associação dos Geógrafos Brasileiros seção Três Lagoas, v.1, n.31, p.346-371, jun.2020.

CASTELLS, Manuel. O poder da identidade. Trad. Klauss Brandini Gerhardt. São Paulo: Paz e Terra, 1999.

COSTA, Edgar Aparecido da; ZARATE, Suellen Soares; MACEDO, Hudson Azevedo. Principiar do desenvolvimento territorial no assentamento rural 72, em Ladário-MS, Brasil. In: SAQUET, Marco A.; DANSERO, Egídio; CANDIOTTO, Luciano Z. P. (Orgs). Geografia da e para a cooperação ao desenvolvimento territorial: experiências brasileiras e italianas. São Paulo: Outras Expressões, 2012. p.125-145.

EDUARDO, Márcio Freitas. Agroecologia e o processo de ativação de territorialidades camponesas. Revista NERA, Presidente Prudente, Ano 19, n. 31, p. 143-165, maiago.2016.

FALS BORDA, Orlando. La ciencia y el pueblo: In: GROSSI, F.; GIANOTTEN, V.; WIT, T. (Org.). Investigación participativa y praxis rural. Lima: Mosca Azul, 1981. p.19-47.

GLIESSMAN, Stephen R. Agroecología: plantando las raíces de la resistencia. Agroecología, v. 8, n. 2, p. 19-26, 2013.

HORT, Juliane; BERWALDT, Jean Carlos. Capa: a experiência luterana entre agricultores familiares no Oeste do Paraná. Geografia em questão, v.11, n.01, p.29-42, 2018.

IBGE. Censo Agropecuário 2017. Rio de Janeiro: IBGE, 2017.

IBGE. Estimativa da população. Rio de Janeiro: IBGE, 2020.

IBGE. Pesquisa da Agricultura Municipal. Rio de Janeiro: IBGE, 2019a.

IBGE. Pesquisa da Pecuária Municipal. Rio de Janeiro: IBGE, 2019b.

LE BOURLEGAT, Cleonice Alexandre. Campo Grande e o estado do Mato Grosso do Sul no centro da rota sul-americana dos litorais atlântico e pacífico. Multitemas, n.8, p.169-190, fev.1998. 
MATO GROSSO DO SUL. Zoneamento Ecológico-Econômico: elementos para construção da sustentabilidade do território sul-mato-grossense. Campo Grande: Secretaria de Estado de Meio Ambiente, Desenvolvimento Econômico, Produção e Agricultura Familiar, 2015.

MORAES, Ênio G.; CURADO, Fernando F. Os limites do associativismo na agricultura familiar de assentamentos rurais em Corumbá, MS. Anais... SIMPÓSIO SOBRE RECURSOS NATURAIS E SOCIOECONÔMICOS DO PANTANAL, 4. Corumbá: Embrapa, 2004.

NASCIMENTO, Jaqueline Silva; BEZERRA, Gleicy Jardi; SCHLINDWEIN, Madalena Maria; PADOVAN, Milton Parron. Produção agropecuária, agregação de valor e comercialização pela agricultura familiar no estado do Mato Grosso do Sul. Redes, Santa Cruz do Sul, v.21, n.3, p.320-334, set./dez.2016.

OLIVEIRA, Ariovaldo Umbelino de. Modo de produção capitalista, agricultura e reforma agrária. São Paulo: Labur Edições, 2007.

QUINTANAR, Silvia; LÓPEZ, Rodolfo. O plano de ação para a Integração da Infraestrutura Regional Sul americana (Iirsa): oportunidades e riscos. Seu significado para o Brasil e a Argentina. Revista Brasileira de Política Internacional, Brasília, v.46, n.1, p.213-221, jan-jun.2003.

SANTOS, Milton. A Natureza do espaço. Técnica e tempo. Razão e emoção. 4.ed. São Paulo: Editora da Universidade de São Paulo, 2006.

SAQUET, Marcos Aurélio. Uma Geografia (i)material voltada para a práxis territorial popular e descolonial, Revista NERA, v.24, n.57, p.54-77, 2021.

SAQUET, Marcos Aurélio. Agricultura camponesa e práticas (agro)ecológicas: abordagem territorial histórico-crítica, relacional e pluridimensional. Mercator, Fortaleza, v.13, n.2, p.125-143, mai./ago.2014.

SHANIN, Teodor. Lições camponesas. In. PAULINO, E. T.; FABRINI, J. E. Campesinato e territórios em disputa. São Paulo: Editora Expressão Popular, 2008. p. 23-48.

TAVARES DOS SANTOS, José Vicente. Colonos do vinho: estudo sobre a subordinação do trabalho camponês ao capital. 2.ed. São Paulo: Hucitec, 1984.

Recebido em 22/10/2021.

Aceito para publicação em 22/11/2021. 